\title{
Modern Minerals Formation Genesis in Kavalerovsky Tin-Ore District Technogenic System (Primorsky Krai)
}

\author{
Valentina Zvereva ${ }^{1}$, Anastasiya Lysenko ${ }^{1}$ and Konstantin Frolov ${ }^{2, *} \mathbb{C}$ \\ 1 Laboratory of Hypergene Processes Geochemistry, Far East Geological Institute, Far Eastern Branch, Russian \\ Academy of Sciences, 159 Prospekt 100-letiya, 690022 Vladivostok, Russia; zvereva@fegi.ru (V.Z.); \\ lion8888@inbox.ru (A.L.) \\ 2 Department of Chemical and Resource-saving Technologies, School of Natural Sciences, Far Eastern Federal \\ University, 8 Sukhanova St., 690090 Vladivostok, Russia \\ * Correspondence: konstantin.fk@gmail.com
}

Received: 9 December 2019; Accepted: 17 January 2020; Published: 21 January 2020

\begin{abstract}
Parameters and conditions of crystallization for the majority of hypergenic and technogenic minerals have not yet been studied, as their determination is often difficult due to their imperfect crystalline structure (X-ray amorphous) and formation in polymineral compounds. The article discusses the formation conditions of 20 hypergenic and technogenic minerals from technogenic waters in the mining industrial system of the Kavalerovsky district tin-sulfide deposits (Primorsky krai) in Russia. For various ratios of hypogenic minerals-host rocks in ore and in tailings in a wide temperature range (from -25 to $45^{\circ} \mathrm{C}$ ), the Eh-pH parameters and the minerals paragenesis were established. All hypergenic and technogenic minerals formed during modeling were found and diagnosed in the Kavalerovsky tin-ore district mining industrial technogenic system.
\end{abstract}

Keywords: physicochemical modeling; hypergenesis; technogenesis; hypergenic and technogenic minerals; association or paragenesis; enrichment tailings; technogenic waters (mine; sludge and drainage)

\section{Introduction}

The article shows the origin of hypergenic and technogenic minerals in nature on the example of the mining industrial system of the Kavalerovsky district tin-sulfide deposits (Primorsky krai) in Russia. Genesis is one of the complex issues of mineralogy, which is poorly covered in the scientific literature for hypergenic and technogenic minerals, due to their imperfect crystalline structure (X-ray amorphous) and formation in polymineral compounds. Sulfide oxidation in open-pit mines and tailings generates highly concentrated solutions from which hypergenic and technogenic minerals crystallize. It is important to know the Eh-pH parameters of the system in which they crystallize, temperature, pressure, association, ratio of primary (hypogenic) minerals, the oxidation of which leads to the formation of secondary (hypergenic and technogenic) minerals, and ratios of hypogenic minerals-host rocks in the tailings.

The Kavalerovsky district is located at the East of Primorsky krai, $450 \mathrm{~km}$ from the regional center, Vladivostok, Russia, and occupies an area of 421,520 hectares (Figure 1). The whole district territory is represented by mountainous terrain, with the Sikhote Alin Ridge passing through [1]. The Kavalerovsky district facilities, including six mines and four concentrating mills of the Khrustalny mining and processing plant, are mainly located in the Zerkalnaya river basin. The mining started in 1941 with the Central (Dubrovskoe) deposit; the remaining mines and concentrating mills started operation in the 1960s and 1970s. In 1992, 15 deposits had been developed by underground mining. 
The main mined element was Sn, and in the 1990s, In and Ag were extracted by-products. Sulfide minerals with an industrial content of $\mathrm{Cu}, \mathrm{Pb}$, and $\mathrm{Zn}$ were always stored in tailings dumps as mining wastes. In 2001, the tin-ore industry of the Kavalerovsky district ceased to exist, but the ore reserves were not depleted.

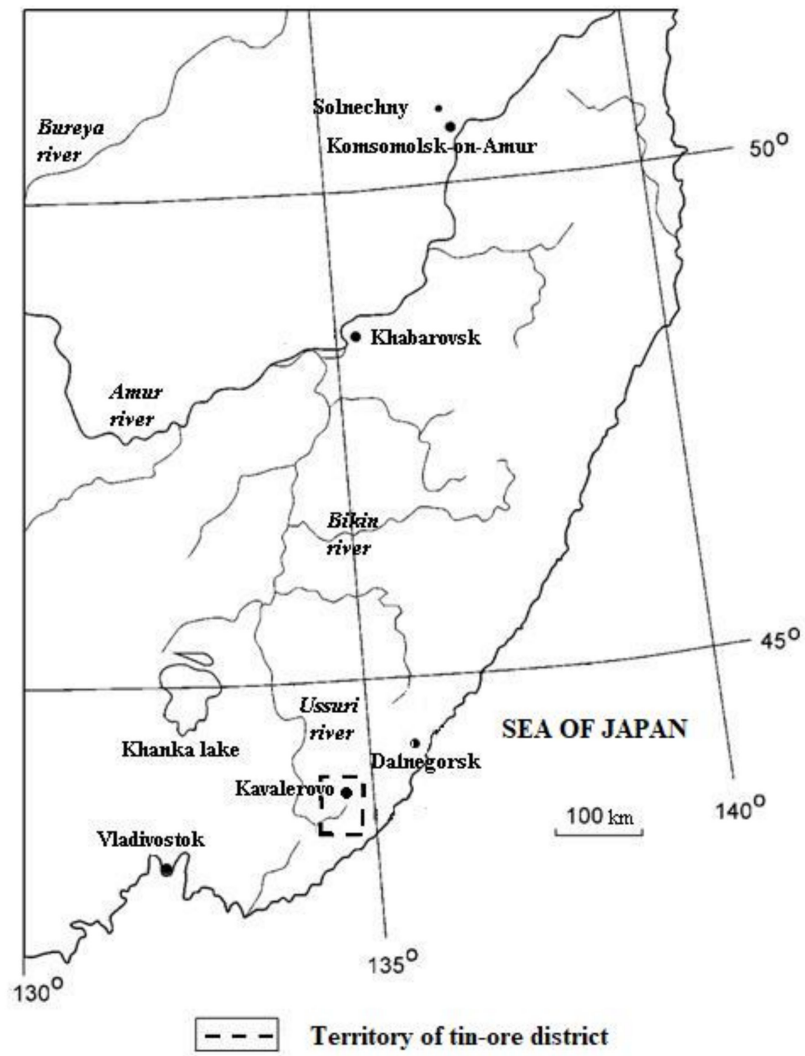

Figure 1. The Kavalerovsky tin-ore district location.

The whole valley of the Fabrichny settlement, where the second largest concentrating mill complex and three big tailing dumps are located, has a large technogenic ecological impact. In the first tailings dump, wastes were stored from 1948 to 1968. Its area is 4 ha and the total weight of tailings is 8 million tons, with an average Sn content of $0.183 \%$. The second and largest tailings dump in the district was in operation from 1968 to 1988. Its area is 7 ha, with a total wastes mass of 21.6 million tons and average Sn content of $0.14 \%$. The third dump of factory wastes ( 4 ha, 5.2 million tons, Sn content of $0.122 \%$ ) was accumulated from 1989 to 1997. The first and second tailings dumps have now been drained, and the third one is a sludge lake less than $1 / 10$ of total object area.

At the second plant in Rudny, the ores of the Dubrovskoe deposit were processed from 1943 to 1990. During these years, a 1.7 ha tailings dump with 2.055 million tons of mining waste was created.

The third concentration mill was located in Vysokogorsk. From 1954 to 1976, the wastes were placed in the tailings dump on the territory of the settlement (1.1 ha, 0.9 million tons).

Quantitative and semi-quantitative spectral analyses of seven samples of the Kavalerovsky district tailings dumps showed that the content of ore elements in the tailings varies within the following content (\%) ranges: $\mathrm{Sn}, 0.04-0.10 ; \mathrm{Cu}, 0.0062-0.2600 ; \mathrm{Pb}, 0.0039-0.0760 ; \mathrm{Zn}, 0.08-1.00 ;$ As, 0.01-0.05; Ni, 0.0014-0.0033; Co, 0.0002-0.0009; Cr, 0.0019-0.0030; V, 0.0043-0.0100; Ag, 0.0003-0.0030; Ga, 0.0011-0.0016; B, 0.01-0.05; Bi, 0.0001-0.0003; Sr, up to 0.01; and Ca, up to 0.1 [2].

All tailings dumps mining wastes are represented by a grey color and finely dispersed mass consisting of pyrite, pyrrhotite, galena, sphalerite, arsenopyrite, chalcopyrite, quartz, fluorite, tourmaline, chlorite, and other minerals. Sometimes iron hydroxides, which are formed by the 
oxidation of sulfides, are colored in different shades of brown. Enrichment wastes are classified as fourth hazard class [3].

The increase in the surface contact of finely ground sulfides with weathering agents in layers of mines and tailings leads to the activation of hypergenic processes, which then transitions to the technogenic stage. The following minerals crystallize: chalcantite, gypsum, halotrichite, melanterite, pittitcite, and many others [2]. Some minerals are seasonal as they are formed during the dry season and disappear during the rainy season.

The purpose of this work was to establish parameters and conditions of crystallization for technogenic minerals that crystallize from technogenic waters using the physico-chemical modeling software complex Selektor. To achieve this goal, we wanted to: (1) determine the Eh-pH parameters of secondary minerals crystallization in a wide temperature range of -25 to $45^{\circ} \mathrm{C}$ in cases of different sulfide minerals to host rock ratios, (2) find the temperature interval of minerals formation in the range of -25 to $45^{\circ} \mathrm{C}$, (3) identify the association or paragenesis of these minerals, (4) consider the dependence of mineral composition formation on the sulfide concentration in the system, and (5) to determine the influence of each sulfide on the Eh-pH system parameters and association of minerals that are formed from highly concentrated technogenic waters.

\section{Materials and Methods}

The formation of hypergenic and technogenic minerals from highly concentrated technogenic waters solutions in the Kavalerovsky tin-ore district was studied using physicochemical modeling. Mineral crystallization occurs in a wide range of Eh-pH system parameters and temperatures.

Physico-chemical modeling was conducted in the Selektor software complex (version 2010, K.V. Chudnenko and I.K. Karpov, Vinogradov Institute of Geochemistry, Siberian Branch of the Russian Academy of Sciences, Irkutsk, Russian Federation) [4]. The program is based on the convex programming mathematical approach, which allows an equilibrium to be established in heterogeneous systems by minimizing thermodynamic potentials (Gibbs energy). In Selektor, the phase and component composition of the thermodynamic multisystem at different temperatures and pressures can be calculated, considering the activity coefficients. Isothermal changes in thermodynamic functions are calculated using an equation of changes in the volume of condensed phases depending on temperature, pressure, and semi-empirical states of gases using the given parameters.

At the initial stage of model formation, the following components were required for systems: independent components, including chemical composition, and dependent components, which potentially exist in models. The dependent components can be present in the following phases and with the following thermodynamic properties: gases (atmospheric and from sulfide oxidation reactions), liquids (ions, molecules, and pieces formed in solutions), and solid (hypogenic, hypergenic, and technogenic minerals of the Kavalerovsky mining industrial system). Both thermodynamic properties are included in the program [4-9], and the values found in relevant sources $[10,11]$ were used in the modeling.

The chemical composition in the models is as follows: atmosphere $(\mathrm{Ar}=3.209 \mathrm{~mol}, \mathrm{C}=0.1036 \mathrm{~mol}$, $\mathrm{N}=53.9478 \mathrm{~mol}, \mathrm{O}=144.8472 \mathrm{~mol})$ [12] for a total of $10 \mathrm{~kg}, 1 \mathrm{~kg}$ water $\left(\mathrm{H}_{2} \mathrm{O}\right)$, and $0.1 \mathrm{~kg}$ minerals or tailings. The following thermobarometric conditions were specified for modeling: temperature from -25 to $45^{\circ} \mathrm{C}$ with a step of $5{ }^{\circ} \mathrm{C}$ and constant 1 bar pressure.

All the above characteristics were added into the Selektor software, which calculated the equilibrium composition of the gas, liquid, and solid phases of the system. The results of modeling were analyzed and verified.

The mineral composition of primary ores and host rocks obtained from the literature sources was used for modeling [13,14], as were drilling data [15]. Mine water formation was modeled as a result of sulfide oxidation (chalcocite, covellite, bornite, pyrite, pyrrhotite, chalcopyrite, arsenopyrite, galena, and sphalerite): each separately, all together, and with successive exclusion of one mineral from the entire list. The formation of slurry and drainage water for closed (long idle) tailings dumps was 
modeled as a result of oxidation of the host rock and sulfides in different ratios. In addition, systems, with the exception of each sulfide, were simulated.

\section{Results and Discussion}

\subsection{Crystallization From Mine Waters}

The calculations included 12 independent (Ar, As, C, Cu, Fe, N, Pb, S, Zn, H, O, and ē, where ē is electron) and 274 dependent components: 210 dissolved particles, 18 gases, and 45 solid phases (most probable hypogene and hypergene minerals and ice).

The results of sulfide oxidation modeling in the mine workings within the positive temperature range have been partially published for many districts [16]. The results of modeling 21 sulfide oxidation variants in the considered temperature range are presented below. The formation of highly concentrated mine waters led to crystallization of the following minerals: fibroferrite, chalcantite, posnjakite, wroewolfeite, antlerite, anglesite, bayldonite, and olivenite. In cryogenesis conditions, additional goslarite and duftite precipitate (Table 1).

Table 1. Conditions of hypergenic minerals crystallization from technogenic waters.

\begin{tabular}{|c|c|c|}
\hline Mineral & Eh-pH & $\mathrm{T}\left({ }^{\circ} \mathrm{C}\right)$ \\
\hline \multicolumn{3}{|c|}{ oxides and hydroxides } \\
\hline $\begin{array}{c}\text { goethite } \mathrm{FeO} \cdot \mathrm{OH} \\
\text { tenorite } \mathrm{CuO}\end{array}$ & $\begin{array}{l}0.42-1.10 \mathrm{~V}, 2.4-14.7 \\
0.42-0.52 \mathrm{~V}, 11.8-13.3 \\
\text { llfates }\end{array}$ & $\begin{array}{l}-25 \text { to } 45 \\
0 \text { to } 45\end{array}$ \\
\hline gypsum $\mathrm{CaSO}_{4} \cdot 2 \mathrm{H}_{2} \mathrm{O}$ & $0.57-1.15 \mathrm{~V}, 1.8-14.1^{*}$ & -25 to 45 \\
\hline fibroferrite $\mathrm{Fe}^{+3}\left[\mathrm{SO}_{4}\right](\mathrm{OH}) \cdot 5 \mathrm{H}_{2} \mathrm{O}$ & $0.60-1.24 \mathrm{~V}, 0.1-13.7^{*}$ & -25 to 45 \\
\hline chalcanthite $\mathrm{CuSO}_{4} \cdot 5 \mathrm{H}_{2} \mathrm{O}$ & $0.74-1.20 \mathrm{~V}, 0.6-9.9^{*}$ & -25 to $-5,0$ to 45 \\
\hline antlerite $\mathrm{Cu}_{3}\left[\mathrm{SO}_{4}\right](\mathrm{OH})_{4}$ & $0.98-1.06 \mathrm{~V}, 2.4-4.0$ & 35 to 45 \\
\hline posnjakite $\mathrm{Cu}_{4}\left[\mathrm{SO}_{4}\right](\mathrm{OH})_{6} \cdot \mathrm{H}_{2} \mathrm{O}$ & $0.98-1.06 \mathrm{~V}, 2.7-3.9$ & 20 to 45 \\
\hline wroewolfeite $\mathrm{Cu}_{4}\left[\mathrm{SO}_{4}\right](\mathrm{OH})_{6} \cdot 2 \mathrm{H}_{2} \mathrm{O}$ & $0.74-1.15 \mathrm{~V}, 1.8-10.0^{*}$ & -25 to $-5,0$ to 45 \\
\hline woodwardite $\mathrm{Cu}_{4} \mathrm{Al}_{2}\left[\mathrm{SO}_{4}\right](\mathrm{OH})_{12 \bullet} 4 \mathrm{H}_{2} \mathrm{O}$ & $0.42-1.15 \mathrm{~V}, 1.8-14.7^{*}$ & -25 to 45 \\
\hline goslarite $\mathrm{Zn}\left[\mathrm{SO}_{4}\right] \cdot 7 \mathrm{H}_{2} \mathrm{O}$ & $1.06-1.17 \mathrm{~V}, 1.3-1.4$ & -25 to -20 \\
\hline anglesit $\mathrm{PbSO}_{4}$ & $0.75-1.18 \mathrm{~V}, 0.8-8.0$ & -25 to 45 \\
\hline starkeyite $\mathrm{MgSO}_{4} \bullet 4 \mathrm{H}_{2} \mathrm{O}$ & $0.50-1.15 \mathrm{~V}, 1.8-14.7^{*}$ & -25 to -5 \\
\hline alunogen $\mathrm{Al}_{2}\left[\mathrm{SO}_{4}\right]_{3} \cdot 17 \mathrm{H}_{2} \mathrm{O}$ & $0.68-1.15 \mathrm{~V}, 1.1-10.8^{*}$ & -25 to 45 \\
\hline \multicolumn{3}{|c|}{ carbonates } \\
\hline magnesite $\mathrm{MgCO}_{3}$ & $0.42-0.75 \mathrm{~V}, 7.4-14.7$ & -25 to 45 \\
\hline \multicolumn{3}{|c|}{ arsenates } \\
\hline scorodite $\mathrm{Fe}^{+3}\left[\mathrm{AsO}_{4}\right] \cdot 2 \mathrm{H}_{2} \mathrm{O}$ & $0.60-1.0 \mathrm{~V}, 4.1-12.5$ & -25 to -5 \\
\hline olivenite $\mathrm{Cu}_{2}\left[\mathrm{AsO}_{4}\right](\mathrm{OH})$ & $0.50-1.15 \mathrm{~V}, 1.8-14.3$ & -25 to $-5,0$ to 45 \\
\hline bayldonite $\mathrm{Cu}_{3} \mathrm{~Pb}\left[\mathrm{AsO}_{4}\right]_{2}(\mathrm{OH})_{2}$ & $0.50-1.15 \mathrm{~V}, 1.8-14.4$ & -25 to 45 \\
\hline duftite $\mathrm{CuPb}\left[\mathrm{AsO}_{4}\right](\mathrm{OH})$ & $0.42-1.16 \mathrm{~V}, 2.0-14.3$ & -10 to $-5,0$ to 45 \\
\hline \multicolumn{3}{|c|}{ silicates } \\
\hline \multirow{2}{*}{$\begin{array}{c}\text { allophane } \mathrm{m}_{2} \mathrm{O}_{3 \bullet} \mathrm{nSiO}_{2} \bullet \mathrm{pH}_{2} \mathrm{O} \\
\text { montmorillonite } \mathrm{m}\left\{\mathrm{Mg}_{3}\left[\mathrm{Si}_{4} \mathrm{O}_{10}\right](\mathrm{OH})_{2}\right\} \\
\text { p }\left\{\left(\mathrm{Al}, \mathrm{Fe}^{+3}\right)_{3}\left[\mathrm{Si}_{4} \mathrm{O}_{10}\right](\mathrm{OH})_{2}\right\} \bullet \mathrm{nH}_{2} \mathrm{O}\end{array}$} & $0.50-1.15 \mathrm{~V}, 1.8-14.7$ & -25 to 45 \\
\hline & $0.42-0.71 \mathrm{~V}, 9.3-14.7$ & -25 to 45 \\
\hline
\end{tabular}

${ }^{*}$ High alkaline $\mathrm{pH}$ values were found in micropore solutions in the temperature range from -5 to $-25^{\circ} \mathrm{C}$ during mine waters formation (chalcocite and bornite oxidation), and formation of slurry and drainage waters (with high content of host rock minerals, from $60 \%$ to $95 \%$ ), sulfates are precipitated in such cases, but their masses are insignificant and amounts to $0.01-2 \%$ of total precipitated minerals masses.

Formation of fibroferrite from the simulated solutions occurs at Eh-pH values from 0.74 to $1.24 \mathrm{~V}$ and from 0.1 to 5.7 : chalcantite $=0.74-1.20 \mathrm{~V}, 0.6-3.3$; wroewolfeite $=0.74-1.05 \mathrm{~V}, 3.2-3.3$ (in the temperature range from -25 to $\left.30^{\circ} \mathrm{C}\right)$; posnjakite $=1.02-1.03 \mathrm{~V}, 3.2\left(20-35^{\circ} \mathrm{C}\right)$; antlerite $=1.02-1.06 \mathrm{~V}$, 2.4-3.1 $\left(35-45^{\circ} \mathrm{C}\right)$; goslarite $=1.06-1.17 \mathrm{~V}, 1.3-1.4\left(\right.$ from 25 to $\left.-20{ }^{\circ} \mathrm{C}\right)$; anglesite $=1.04-1.18 \mathrm{~V}, 0.8-2.7$; 
bayldonite $=1.09-1.14 \mathrm{~V}, 2.0-2.3\left(-25\right.$ to $\left.20^{\circ} \mathrm{C}\right)$; olivenite $=1.08-1.09 \mathrm{~V}, 2.0-2.3\left(15-45^{\circ} \mathrm{C}\right)$; and duftite $=1.12-1.16 \mathrm{~V}, 2.0\left(-25\right.$ to $\left.-15^{\circ} \mathrm{C}\right)$. The exception is crystallization from highly alkaline solutions ( $\mathrm{pH} 7$ to 10) of fibroferrite, chalcantite, and wroewolfeite during oxidation of chalcocite and bornite in the temperature range from -5 to $-25^{\circ} \mathrm{C}$. Probably, the presence of single-valent copper in structure of chalcosine and boronite promotes the formation of such solutions. This contradicts the generally accepted concepts of crystallization of sulfates in the range of positive temperatures from acid solutions.

Crystallization of wroewolfeite, posnjakite, and antlerite is observed only in the presence of secondary sulfide enrichment (cementation) zone minerals in the ore body: chalcocite and bornite, both separately and together. Chalcantite crystallization occurs in all cases in the presence of copper-bearing sulfides. Olivenite, bayldonite, and duftite are observed only in the primary association of sulfides without pyrrhotite, but in the presence of all minerals in the cementation zone. Goslarite forms only in the case of sphalerite oxidation under cryogenic conditions.

The modeled systems have the following masses of minerals (g): antlerite, 52.0-104.0; chalcanthite, 0.0003-261.0; posnjakite, 0.0001-91.0; wroewolfeite, 0.0001-99.0; goslarite, 0.00008-0.0002; anglesite, 3.0-159.0; fibroferrite, 17.0-294.0; bayldonite, 0.00008-18.0; olivenite, 0.00001-5.0; and duftite, 0.001-22.0. As the temperature rises, the masses of antlerite, wroewolfeite, posnjakite, goslarite, anglesite, and olivenite increase; chalcantite, duftite, and bayldonite decrease; and fibroferrite remains constant.

The formation of mine water occurs when all micropore solutions, the variants of which are described above, are merged. The study of hydrochemical samples of mine waters has shown that in the studied area, the $\mathrm{pH}$ value is in the range from 4.5 to 8.1 [17].

\subsection{Crystallization From Tailings Dumps Sludge and Drainage}

The calculations of technogenic waters (sludge and drainage) modeling included 19 independent (Al, Ar, As, B, C, Ca, Cu, Fe, K, Mg, N, Na, Pb, S, Si, Zn, H, O, and ē) and 371 dependent components: 283 dissolved particles, 18 gases, and 70 solid phases. The obtained results were partly published in works [16,18-27]. Modeling showed that most of the hypergenic minerals (Table 1) crystallize from highly concentrated solutions in the temperature range from -25 to $45^{\circ} \mathrm{C}$.

To create models of sulfide oxidation in contact with host rocks minerals, the composition listed in Tables 2 and 3 was used. As the waste composition in different parts of the tailings dump varies, systems with host-rock-sulfide ratios of 95:5, 90:10, 80:20, and 20:80 were modeled.

Table 2. Sulfide mineral composition of the studied tailings (\%) [13].

\begin{tabular}{cccccc}
\hline Mineral & \multicolumn{3}{c}{ Khrustalnoe Deposit } & Vysokogorsk & Dubrovskoe \\
& 1st & 2nd & 3rd & Deposit & Deposit \\
\hline pyrite $\mathrm{FeS}_{2}$ & 11.33 & 29.33 & 18 & 15 & 30 \\
pyrrhotite $\mathrm{Fe}_{0.877} \mathrm{~S}$ & 1.33 & 8.67 & 4.67 & 20 & 10 \\
arsenopyrite FeAsS & 14.67 & 6.67 & 5.33 & 20 & 10 \\
chalcopyrite $\mathrm{CuFeS}$ & 9.33 & 6.67 & 5.33 & 30 & 10 \\
galena PbS & 43.33 & 19.33 & 23.33 & 5 & 20 \\
sphalerite $\mathrm{ZnS}$ & 20 & 29.33 & 43.33 & 10 & 20 \\
\hline
\end{tabular}

Table 3. Host rock mineral composition of studied tailings (\%) [13].

\begin{tabular}{cccc}
\hline Mineral & Khrustalnoe Deposit & Vysokogorsk Deposit & Dubrovskoe Deposit \\
\hline chlorite $\mathrm{Si}_{3} \mathrm{Al}_{2} \mathrm{Mg}_{5} \mathrm{O}_{10}(\mathrm{OH})_{8}$ & 78.38 & 45.94 & 59.46 \\
sericite $\mathrm{KAl}_{2}\left[\mathrm{AlSi}_{3} \mathrm{O}_{10}\right](\mathrm{OH})_{2}$ & 11.89 & 13.51 & 13.51 \\
tourmaline $\mathrm{NaFe}_{3} \mathrm{Al}_{6}\left[\mathrm{BO}_{3}\right]_{3}\left[\mathrm{Si}_{6} \mathrm{O}_{18}\right](\mathrm{OH})_{4}$ & 5.95 & 35.14 & 21.62 \\
epidote $\mathrm{Ca}_{2} \mathrm{Al}_{2} \mathrm{Fe}_{\left[\mathrm{Si}_{2} \mathrm{O}_{7}\right]\left[\mathrm{SiO}_{4}\right] \mathrm{O}(\mathrm{OH})}$ & 2.16 & 3.24 & 3.24 \\
${\text { calcite } \mathrm{CaCO}_{3}}^{c}$ & 1.62 & 2.16 & 2.16 \\
\hline
\end{tabular}


The processes of tailings oxidation and technogenic minerals formation at Khrustalnoe and Dubrovskoe deposits tailings dumps (Tables 2 and 3) were modeled in the temperature range from 0 to $45{ }^{\circ} \mathrm{C}$. The mineral composition presented in this work is similar to previous works on minerals association but differs in the details (for example, alunogen is observed only in the models of the Khrustalnoe tailings dump). Therefore, we combined all the available results.

From saturated solutions, $\mathrm{Cu}, \mathrm{Fe}, \mathrm{Pb}, \mathrm{Mg}$, and $\mathrm{Al}$ minerals of the following classes precipitate: oxides and hydroxides, sulfates, carbonates, arsenates, and silicates. These are goethite (Eh-pH parameters: $0.42-0.74 \mathrm{~V}$ and $7.5-12.6)$, tenorite and woodwardite $(0.42-0.52 \mathrm{~V}, 11.8-13.3)$, fibroferrite (0.63-0.86 V, 5.6-13.3), gypsum (0.59-0.86 V, 5.6-11.2), alunogen (0.8-0.86 V, 5.6-7.9), magnesite (0.42-0.66 V, 7.5-13.3), duftite and allophane (0.42-0.86 V, 5.6-13.3), and montmorillonite (0.42-0.65 V, 9.3-13.3). Notably, formation of duftite and allophane in the system does not depend on the total sulfide content in tailings; tenorite crystalizes only at 5-10\% sulfide ratios; goethite, woodwardite, and magnesite from 5\% to 60\%; fibroferrite and alunogen within 40-80\%; and anglesite at $80 \%$. The mass of tenorite is $0.20 \mathrm{~g}$, which accounts for $0.1 \%$ of the total precipitated minerals mass.

Tailings oxidation of the Vysokogorsk deposit (Tables 2 and 3) was modeled in the temperature range from -25 to $45^{\circ} \mathrm{C}$. At positive temperatures, the following minerals were established (Table 1): goethite (Eh-pH parameters 0.57-0.75 V, 9.5-10.1, sulfide content in the system from 5\% to 60\%); gypsum and duftite (0.57-1.08 V, 2.7-11.7, from 5\% to 80\% sulfide); woodwardite, magnesite, and allofan (0.57-0.75 V, 7.4-11.6, 5-60\%); alunogen, anglesite, and bayldonite (1.04-1.08 V, 2.7-2.8, 80\%); fibroferrite (0.64-1.08 V, 2.7-10.2, 10-80\%); and montmorillonite (0.57-0.62 V, 9.5-11.6, 5\%). Montmorillonite disappears at a sulfide content of $10 \%$, but fibroferrite appears at $80 \%$, no goethite, woodwardite, and magnesite are found, but alunogen, anglesite, and bayldonite are noted.

At negative temperatures, the following minerals are found (Table 1): goethite and magnesite (0.58-0.74 V, 9.3-10.8, 5-40\%); woodwardite, starkeyite, duftite, and allophane (0.58-1.15 V, 1.8-10.8); wroewolfeite and chalcantite (1.1-1.15 V, 1.8-2.2, 80\%); gypsum, olivenite, and bayldonite (0.71-1.15 V, $1.8-10.8,10-80 \%)$; fibroferrite and alunogen $(0.68-1.15 \mathrm{~V}, 1.8-10.8,40-80 \%)$; and montmorillonite $(0.58-0.71 \mathrm{~V}, 10.6-12.5 \%)$. At a $10 \%$ sulfide content, the montmorillonite disappears, but fibroferrite and scorodite occur; at $80 \%$, no goethite, woodwardite, olivenite, scorodite, magnesite, or allophane exist, but alunogen is precipitated. Woodwardite and duftite only form at $0{ }^{\circ} \mathrm{C}$, and starkeyite, olivenite, bayldonite form in the range from -25 to $-5{ }^{\circ} \mathrm{C}$.

Therefore, oxidation of the total tailings sulfide composition in deposits in the entire temperature range led the system's Eh-pH parameters to change from 0.42 to $1.15 \mathrm{~V}$ and 1.8 to 13.3 . High alkaline $\mathrm{pH}$ values are typical for systems with the content of host rocks from $60 \%$ to $95 \%$ in negative temperature range, but such simulated systems also contain sulfates (fibroferrite, chalcantite, etc.) with insignificant masses (from 0.0001 to $0.5 \mathrm{~g}$ ). Total dissolved solids (TDS) in the positive temperature range after minerals crystallization varies from 11.7 to $72.7 \mathrm{~g} / \mathrm{L}$. The TDS increases significantly under cryogenesis conditions with ice crystallization and liquid phase reduction.

\subsection{Successive Sulfide Minerals Exclusion}

Next, we considered the models with successive exclusion of each sulfide mineral (Figures 2-13).

If pyrite (Figure 2) is excluded from the primary composition, in the positive temperature range, $\mathrm{Fe}, \mathrm{Cu}, \mathrm{Pb}, \mathrm{Al}$, and $\mathrm{Mg}$ minerals of oxides and hydroxides, sulfates, arsenates, carbonates, and silicates precipitate from the saturated solution (Eh-pH parameters): goethite and magnesite (0.58-0.75 V, 7.4-11.7); fibroferrite (0.67-1.09 V, 2.5-10.2); woodwardite (0.56-0.85 V, 7.4-11.7); gypsum, duftite, and allophane (0.58-1.09 V, 2.5-11.7); bayldonite and anglesite (1.05-1.09 V, 2.5-2.6); and montmorillonite (0.59-0.62 V, 9.4-10.3). Changes in the qualitative composition of hypergenic minerals depend on the concentration of the sulfide component in the system: some minerals disappear, including montmorillonite at $20 \%$, goethite and magnesite at $60 \%$, woodwardite and allophane at $80 \%$; and others appear, including gypsum at $10 \%$, fibroferrite at $20 \%$, alunogen at $60 \%$, and anglesite with bayldonite at $80 \%$. Anglesite exists in the range from 20 to $45^{\circ} \mathrm{C}$. 


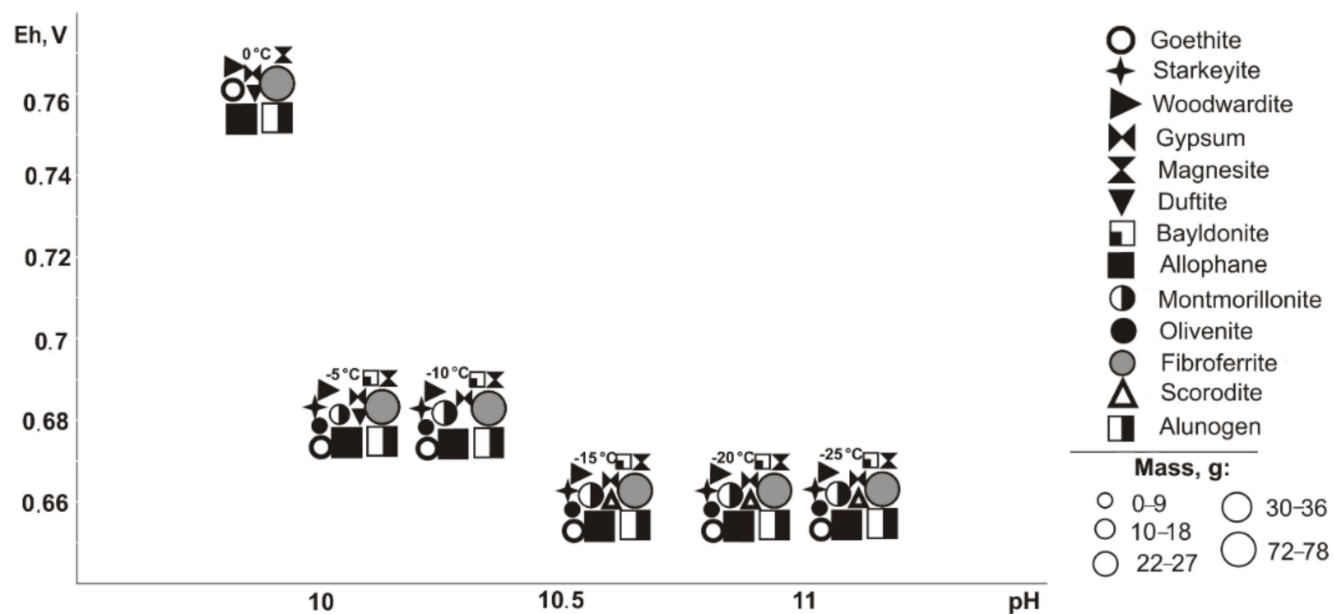

Figure 2. Dependence of mineral masses on Eh-pH parameters in the Vysokogorsk tailings dump in the system without pyrite $\left(\mathrm{T}=-25\right.$ to $\left.0{ }^{\circ} \mathrm{C}\right)$.

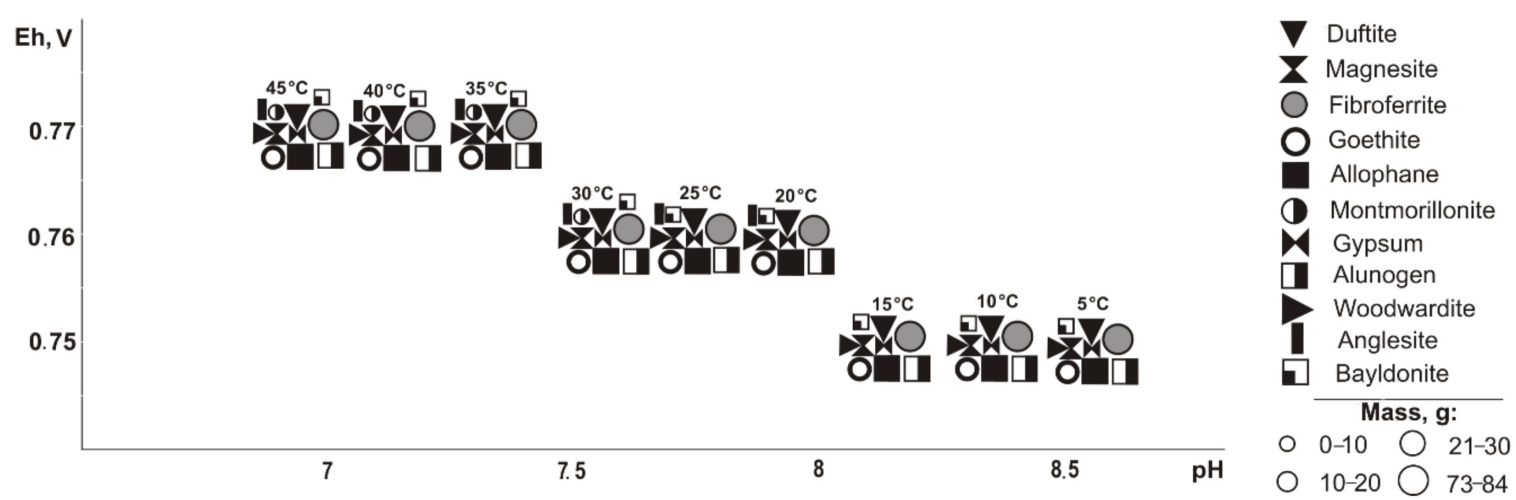

Figure 3. Dependence of mineral masses on Eh-pH parameters at Vysokogorsk tailings dump in system without pyrite $\left(\mathrm{T}=0-45^{\circ} \mathrm{C}\right)$.
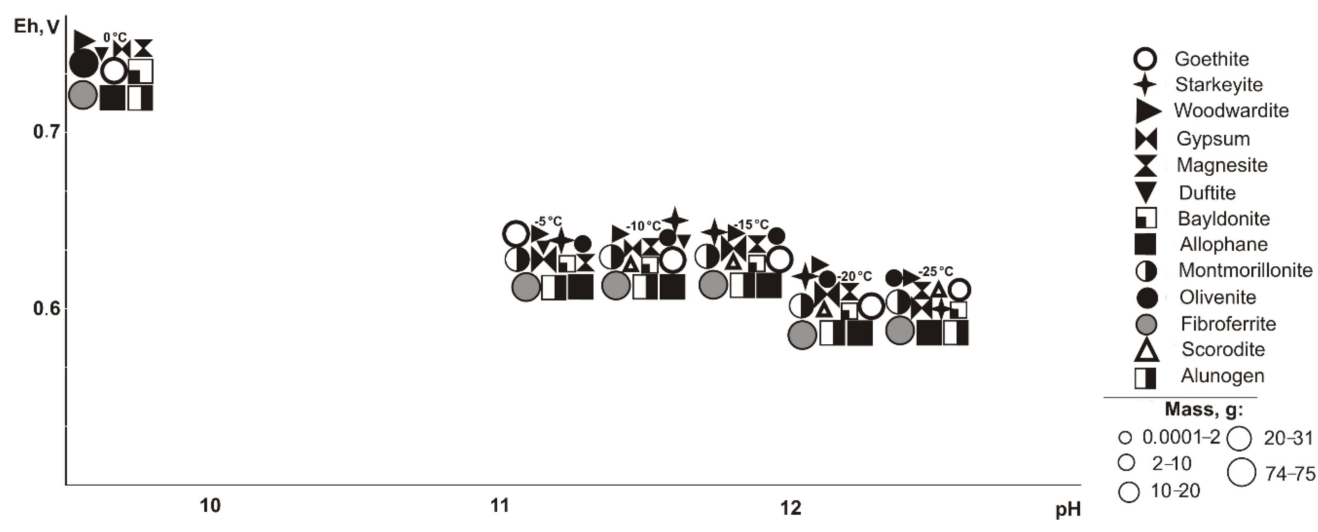

Figure 4. Dependence of mineral masses on Eh-pH parameters at the Vysokogorsk tailings dump in system without pyrrhotite $\left(\mathrm{T}=-25\right.$ to $\left.0{ }^{\circ} \mathrm{C}\right)$. 


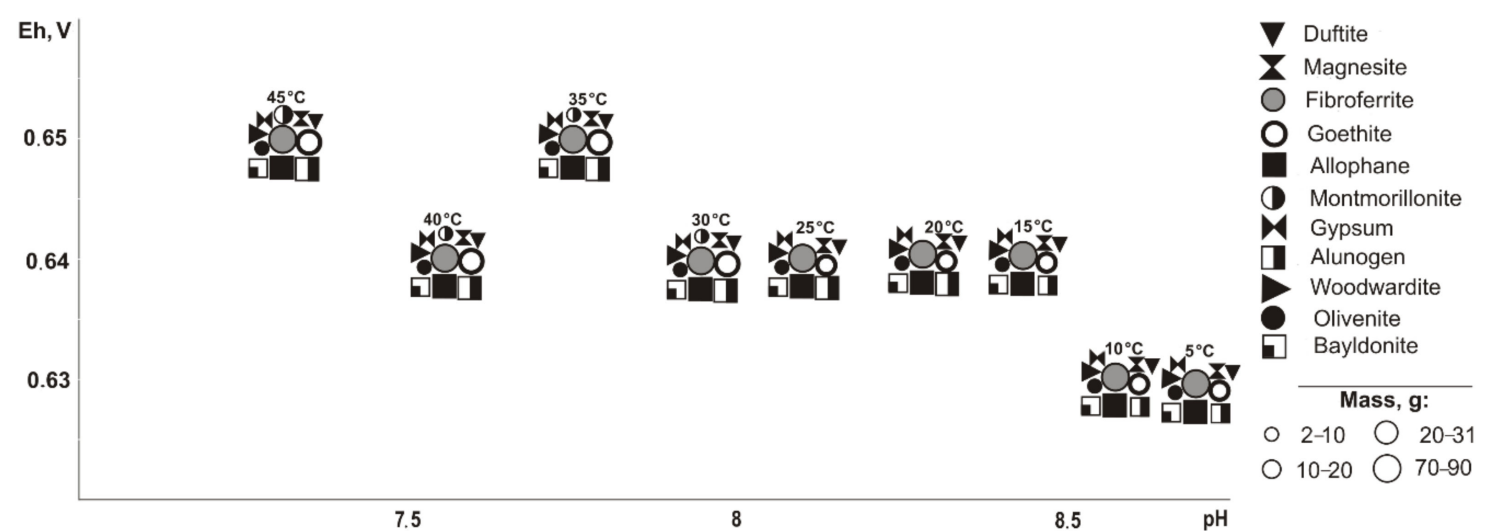

Figure 5. Dependence of mineral masses on Eh-pH parameters at the Vysokogorsk tailings dump in system without pyrrhotite $\left(\mathrm{T}=0-45^{\circ} \mathrm{C}\right)$.

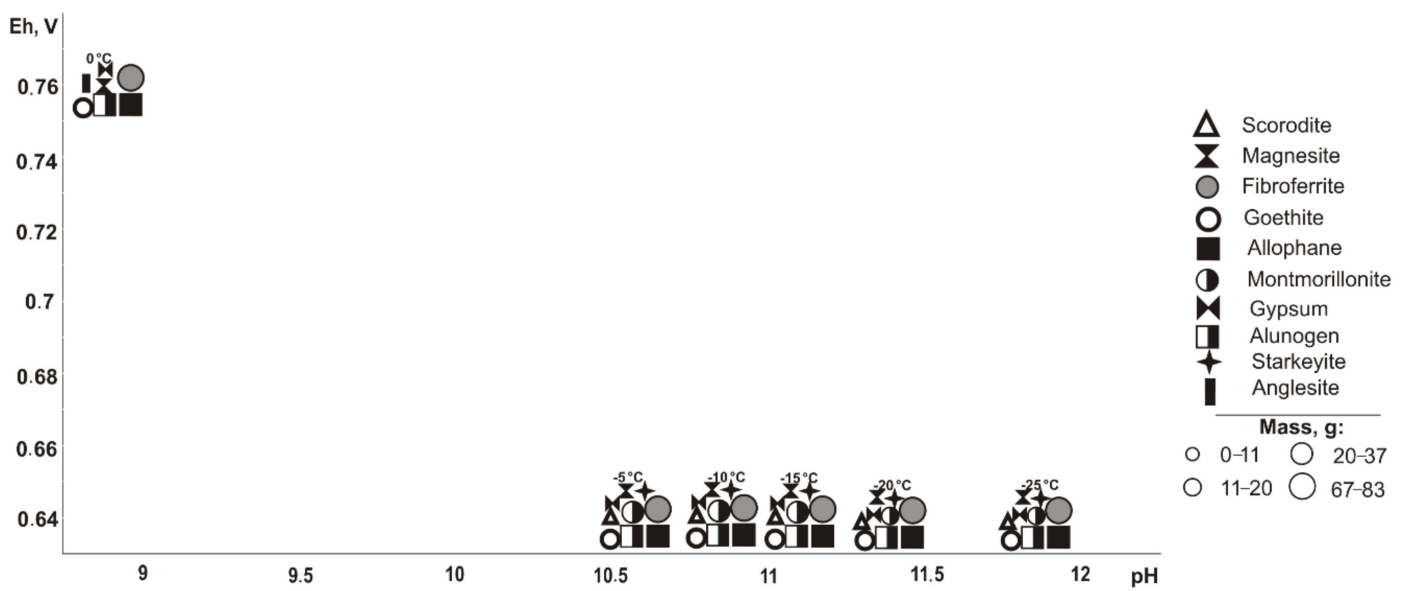

Figure 6. Dependence of mineral masses on Eh-pH parameters at the Vysokogorsk tailings dump in the system without chalcopyrite $\left(\mathrm{T}=-25\right.$ to $\left.0{ }^{\circ} \mathrm{C}\right)$.

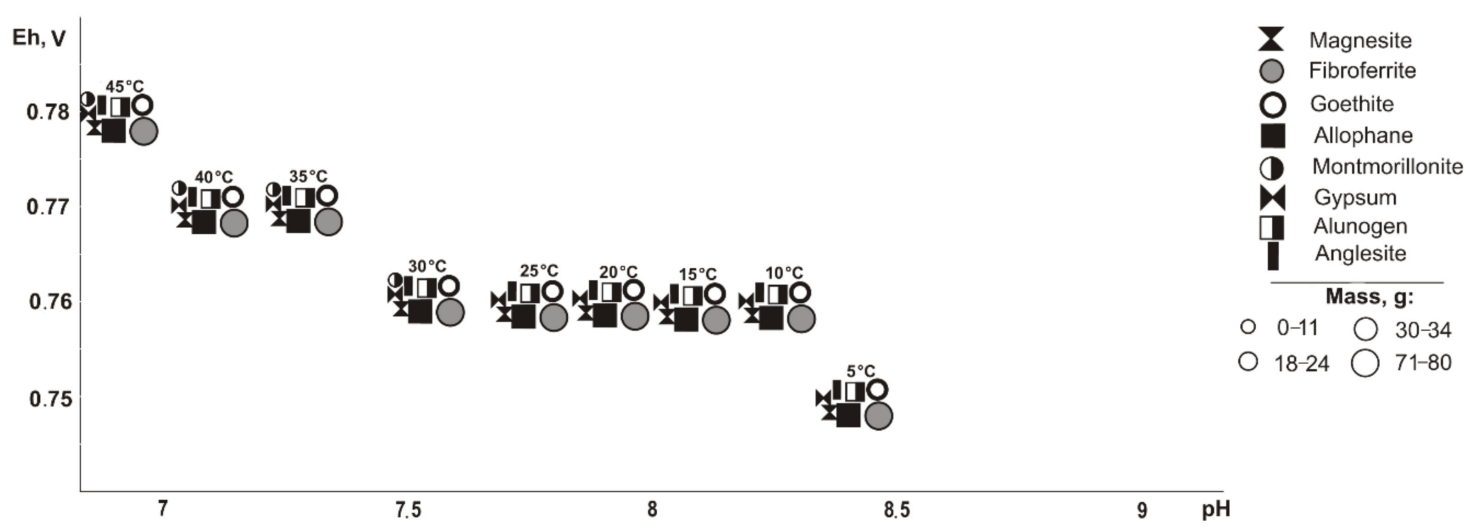

Figure 7. Dependence of mineral masses on Eh-pH parameters at the Vysokogorsk tailings dump in the system without chalcopyrite $\left(\mathrm{T}=0-45^{\circ} \mathrm{C}\right)$. 


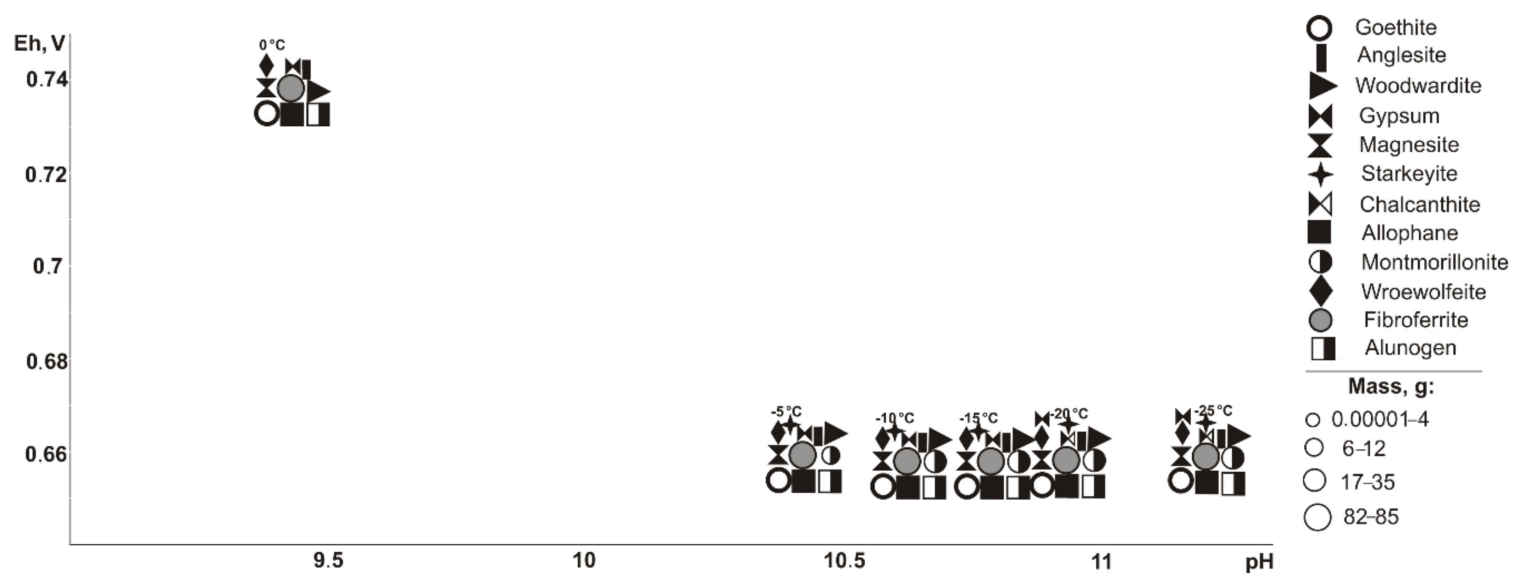

Figure 8. Dependence of mineral masses on Eh-pH parameters at the Vysokogorsk tailings dump in the system without arsenopyrite $\left(\mathrm{T}=-25\right.$ to $\left.0^{\circ} \mathrm{C}\right)$.

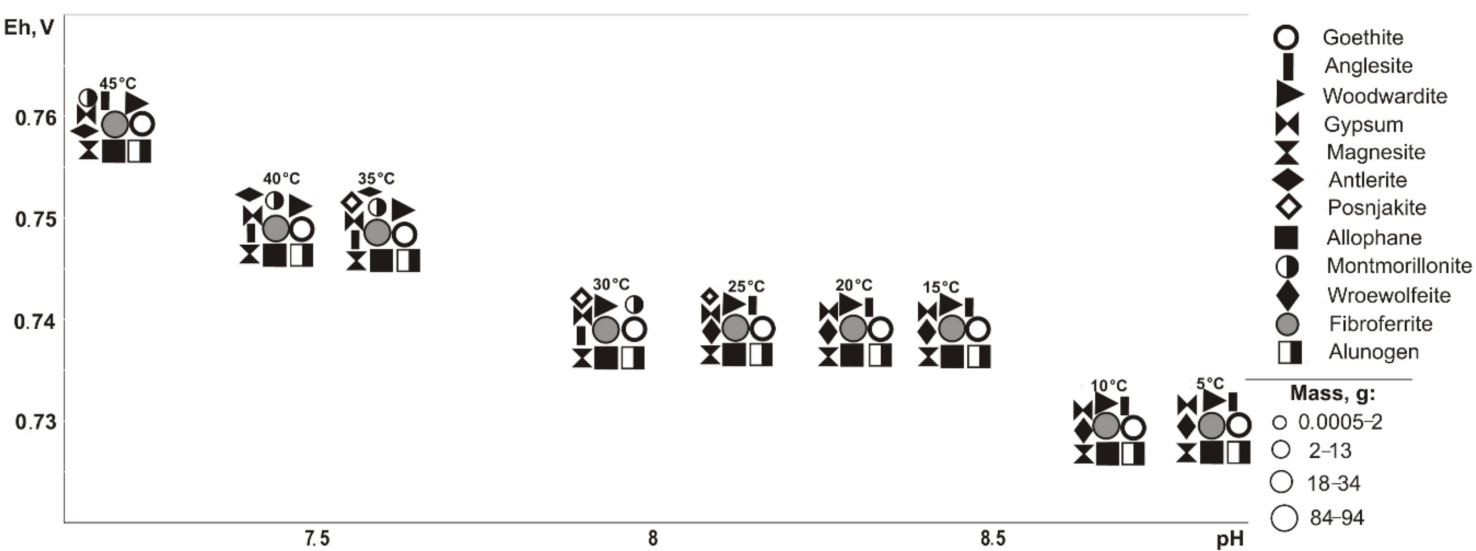

Figure 9. Dependence of mineral masses on Eh-pH parameters at the Vysokogorsk tailings dump in the system without arsenopyrite $\left(\mathrm{T}=0-45^{\circ} \mathrm{C}\right)$.

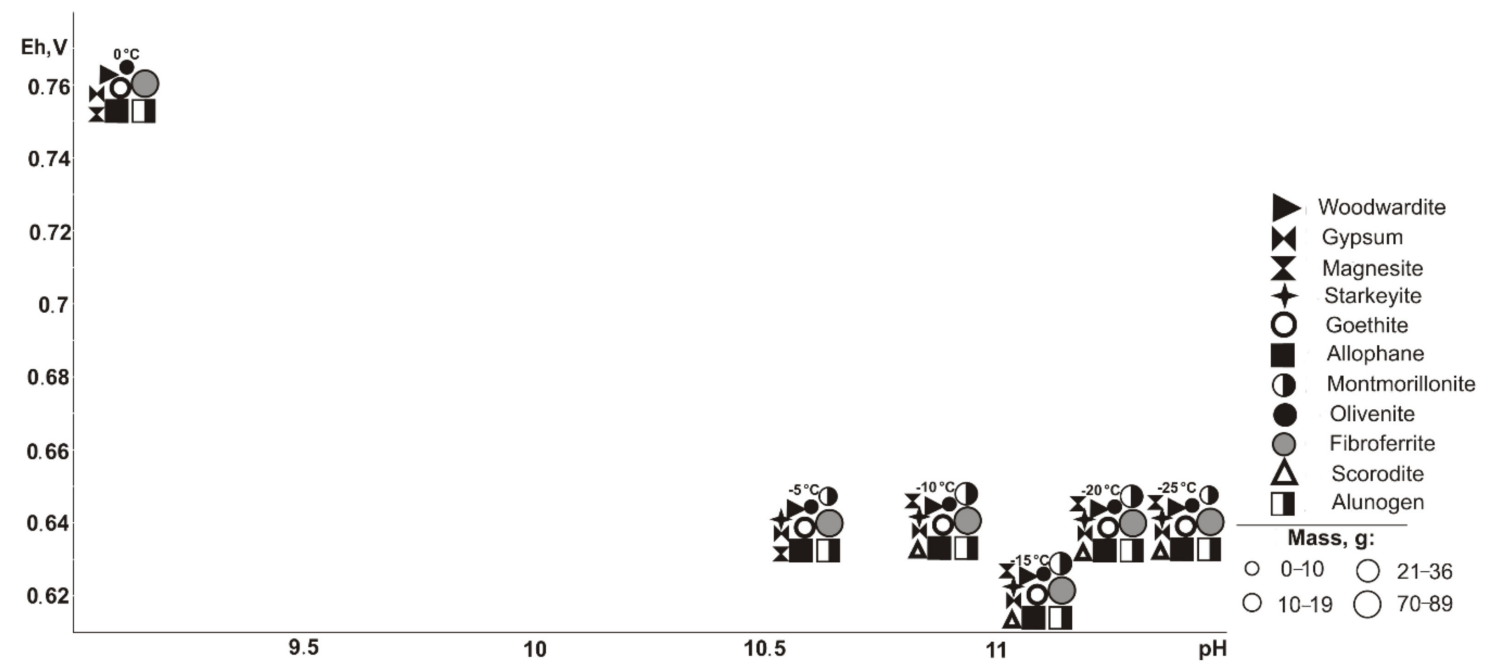

Figure 10. Dependence of mineral masses on Eh-pH parameters at the Vysokogorsk tailings dump in the system without galena $\left(\mathrm{T}=-25\right.$ to $\left.0^{\circ} \mathrm{C}\right)$. 


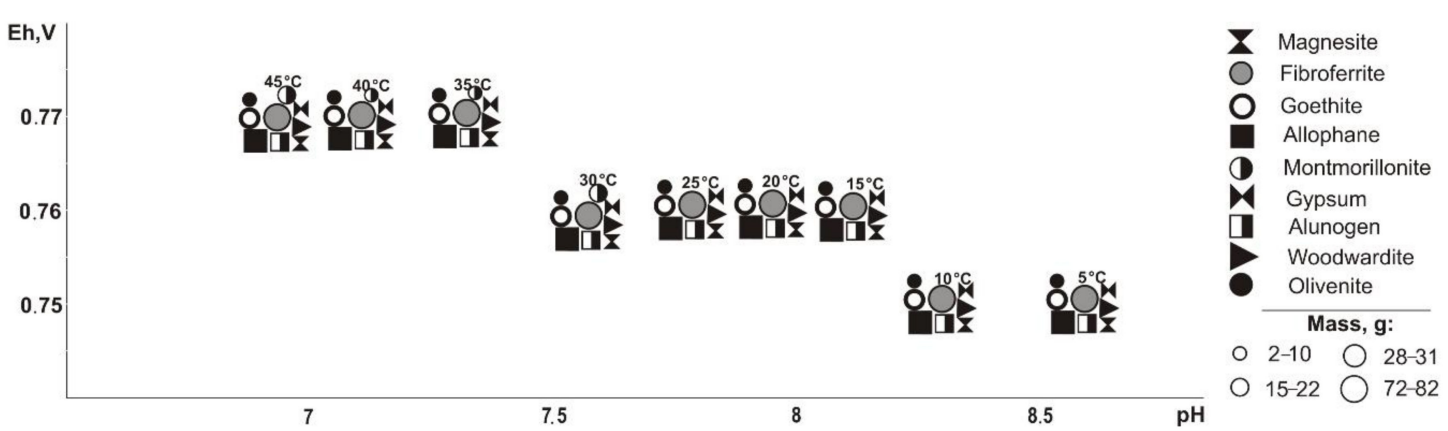

Figure 11. Dependence of mineral masses on Eh-pH parameters at the Vysokogorsk tailings dump in the system without galena $\left(\mathrm{T}=0-45^{\circ} \mathrm{C}\right)$

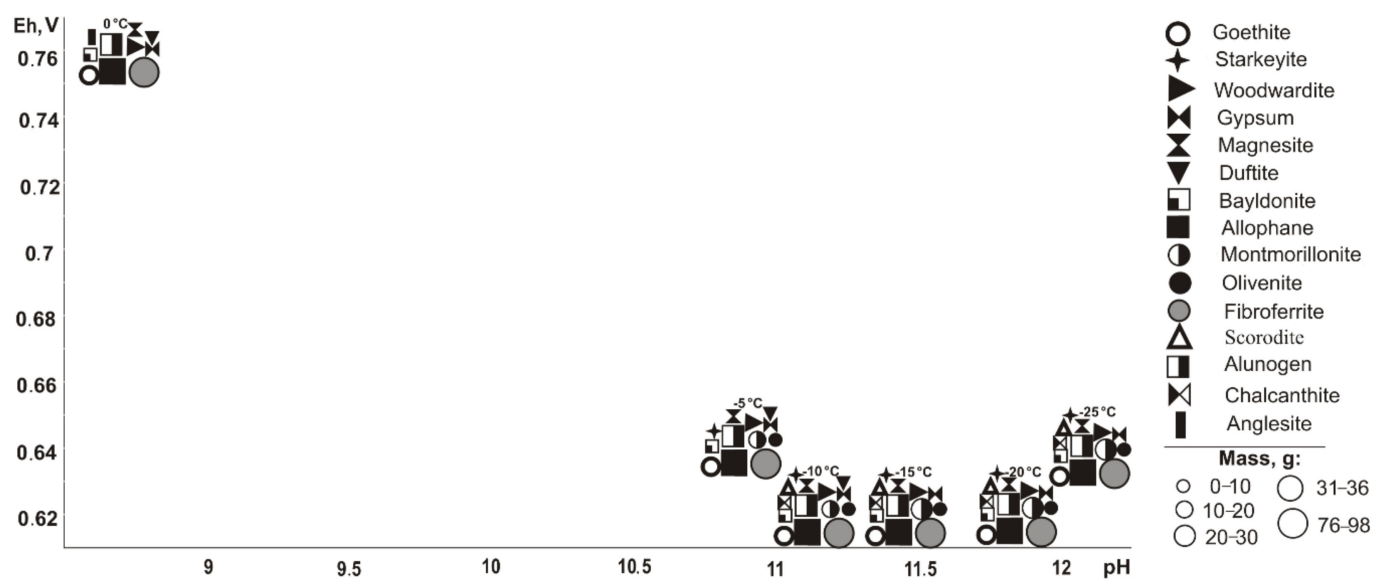

Figure 12. Dependence of mineral masses on Eh-pH parameters at the Vysokogorsk tailings dump in the system without sphalerite $\left(\mathrm{T}=-25\right.$ to $\left.0{ }^{\circ} \mathrm{C}\right)$.

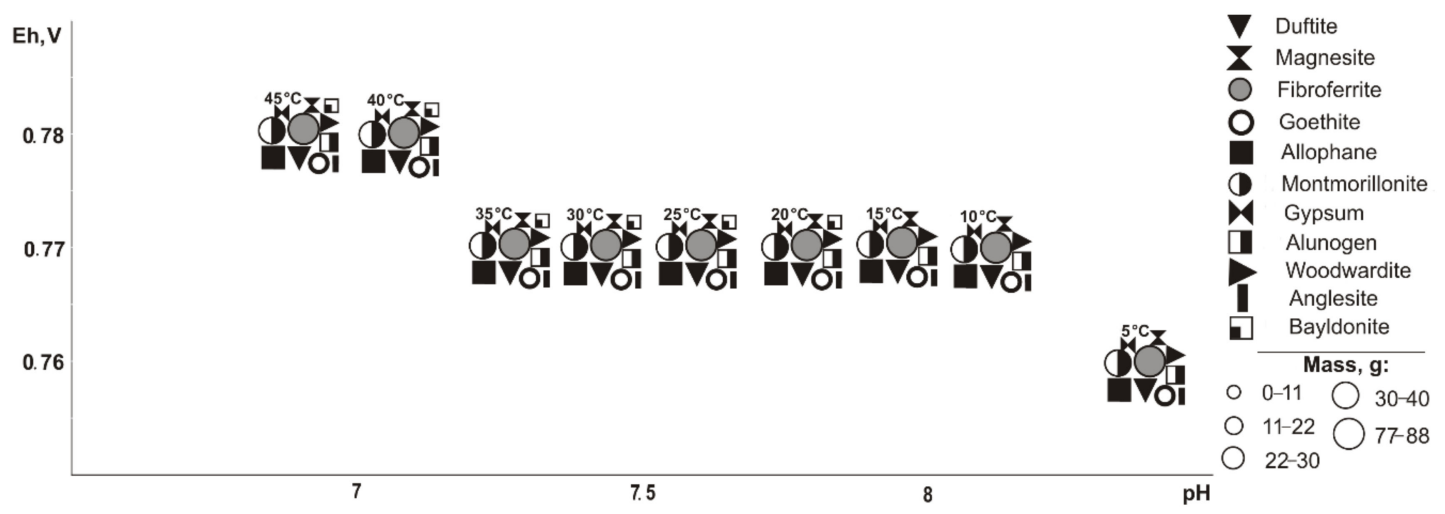

Figure 13. Dependence of mineral masses on Eh-pH parameters at the Vysokogorsk tailings dump in the system without sphalerite $\left(\mathrm{T}=25-45^{\circ} \mathrm{C}\right)$.

In the range of negative temperatures (Figure 3), the following minerals crystallize (Eh-pH): goethite, starkeyite, bayldonite, and olivenite $(0.5-1.1 \mathrm{~V}, 2.4-14.3)$; fibroferrite $(0.6-1.1 \mathrm{~V}, 2.4-12.5)$, woodwardite, magnesite, and allophane (0.5-0.7 V, 10.1-14.3); gypsum (0.6-1.1 V, 2.4-14.0); alunogen (1.1 V, 2.4-2.5); scorodite (0.6-0.7 V, 10.1-12.5); duffitite (0.5-0.7, 10.3-14.3); and montmorillonite (0.5-0.6 V, 12.3-14.3). The following minerals disappear from the association at the following sulfide contents: woodwardite at $10 \%$, montmorillonite at $20 \%$, allophane at $40 \%$, and goethite, magnesite, baildonite, and soononite at $80 \%$; however, the following appear: olivenite at $10 \%$, and fibroferrite and soonite at $20 \%$. Woodwardite occurs within the temperature range from -25 to $-15{ }^{\circ} \mathrm{C}$, and duftite from -10 to $-5{ }^{\circ} \mathrm{C}$ and alunogen at -25 to $0{ }^{\circ} \mathrm{C}$. 
When pyrrhotite is removed from the systems (Figure 4), the same minerals form as when pyrite is excluded, but the parameters of their crystallization are slightly different (Eh-pH): goethite and magnesite (0.58-0.75 V, 7.4-11); fibroferrite (0.67-1.0 V, 3.9-10.2); gypsum (0.61-1.0 V, 3.9-10.5); woodwardite, duftite, and allophane (0.58-0.81 V, 6.6-11.8); alunogen (0.8-1.0 V, 3.9-7.9); olivenite and baildonite (0.97-1.0 V, 3.9-4.1); and montmorillonite (0.58-0.62 V, 9.7-9.9). The qualitative composition of hypergenic minerals differs from the previous variant (without pyrite) as olivenite, instead of anglesite, precipitates at a sulfide content of $80 \%$. Montmorillonite crystallizes in the range from 30 to $45^{\circ} \mathrm{C}$.

Under cryogenic conditions (Figure 5), the following minerals (Eh-pH) are determined in the association: goethite, magnesite, and allophane (0.5-0.7 V, 10.1-14.3); gypsum (0.5-1.0 V, 4.1-14.3), woodwardite (0.5-0.7 V, 10.5-14.3); starkeyite and baildonite (0.5-1.0 V, 4.1-14.3); fibroferrite (0.6-1.0 V, 4.1-12.5); alunogen (0.8-1.0 V, 1.1-8.9); duffitite (0.5 V, 13.5); olivenite (0.5-1.0 V, 4.1-14.0); scorodite (0.6-1.0 V, 4.1-12.2); and montmorillonite (0.5-0.7 V, 12.3-14.3). Olivenite appears at a $10 \%$ sulfide content, fibroferrite and scorodite at $20 \%$, alunogen at $80 \%$, duftite disappears at $10 \%$, woodwardite and montmorillonite at $20 \%$, and goethite, magnesite, speed, and allophane at $80 \%$. Duftite is seen in the range from -10 to $-5{ }^{\circ} \mathrm{C}$.

In the absence of chalcopyrite (Figure 6), all copper-containing minerals disappear from the models. In the range of positive temperatures in the models, the following are formed (Eh-pH): goethite and magnesite (0.59-0.95 V, 7.4-11.7), gypsum (0.59-1.11 V, 2.1-11.7), fibroferrite (0.67-1.11 V, 2.1-11.7), alunogen and anglesite (0.8-1.11 V, 2.1-7.9), allophane (0.59-0.86 V, 5.7-11.7), and montmorillonite (0.57-0.61 V, 9.5-10.8). The sulfide component influences the qualitative composition of hypergenic minerals as follows: montmorillonite (at 10\% sulfide content), goethite and magnesite (60\%), and allophane $(80 \%)$, however, the following appear: fibroferrite $(10 \%)$, alunogen, and anglesite $(60 \%)$. Montmorillonite was detected only at a 5\% sulfide content and temperatures between 30 and $45^{\circ} \mathrm{C}$.

At negative temperatures (Figure 7), the paragenesis of minerals includes (Eh-pH): goethite, magnesite, and allophane (0.5-0.7 V, 10.2-14.1); gypsum and starkeyite (0.5-1.1 V, 2.1-14.1); fibroferrite (0.6-1.1 V, 2.1-13.3); alunogen (0.9-1.1 V, 2.1-6.8); scorodite (0.6-0.7 V, 10.2-12.5); and montmorillonite (0.5-0.6 V, 12.2-14.1). Fibroferrite appears in association at a $10 \%$ sulfide content in the system and alunogen at $80 \%$, scorodite appears at $20-40 \%$, and goethite, magnesite, and allophane disappear at $80 \%$.

Models without arsenopyrite (Figure 8) do not contain arsenate-class minerals. Minerals (Eh-pH) that crystallize at temperatures from 0 to $45{ }^{\circ} \mathrm{C}$ include: goethite and magnesite $(0.58-0.74 \mathrm{~V}$, 7.4-11.8), gypsum (0.62-1.01 V, 3.4-10.4), woodwardite and allophane (0.58-0.85 V, 5.8-11.8), fibroferrite (0.67-1.01 V, 3.4-10.2), alunogen and anglesite (0.75-1.01 V, 3.4-8.0), antlerite (0.98-1.01 V, 3.9-4.0), posnjakite $(0.98 \mathrm{~V}, 3.9)$, wroewolfeite $(0.98-1.01 \mathrm{~V}, 3.4-4.0)$, and montmorillonite $(0.57-0.61 \mathrm{~V}, 9.5-10.7)$. The following minerals disappear from the system at various sulfide contents (\%): montmorillonite $(20 \%)$, goethite and magnesite $(60 \%)$, and woodwardite and allophane $(80 \%)$; however, the following appear: gypsum (10\%), fibroferrite (20\%), alunogen and anglesite $(60 \%)$, as well as antlerite, posnjakite, and wroewolfeite $(80 \%)$. Posnjakite forms in the temperature range from 25 to $45^{\circ} \mathrm{C}$, antlerite at $35-45{ }^{\circ} \mathrm{C}$, and wroewolfeite at $0-25{ }^{\circ} \mathrm{C}$.

At temperatures below $0{ }^{\circ} \mathrm{C}$ (Figure 9), the models show (Eh-pH): goethite, woodwardite, magnesite, and allophane (0.5-0.7 V, 10.3-14.7); gypsum (0.6-0.7 V, 10.3-12.4); fibroferrite (0.6-1.1 V, 2.0-12.7); starkeyite (0.5-1.1 V, 2.0-14.7); alunogen, wroewolfeite, and anglesite (1.0-1.1 V, 2.0-4.0), chalcantite (1.1 V, 2.0-2.1); and montmorillonite (0.5 V, 13.2-14.7). Montmorillonite is absent in the models with a $20 \%$ sulfide content, and goethite, woodwardite, magnesite and allophane are absent in the models with a $80 \%$ sulfide content, but in the latter variant, alunogen, wroewolfeite, and chalcantite crystallize only in the range from -25 to $-20{ }^{\circ} \mathrm{C}$, as does anglesite.

Removal of galena (Figure 10) resulted in the absence of lead minerals in the models. In the interval of positive temperatures $(\mathrm{Eh}-\mathrm{pH})$, the following minerals form: goethite and magnesite $(0.59-0.75 \mathrm{~V}$, 
7.4-11.6), gypsum (0.59-1.07 V, 2.8-11.6), fibroferrite (0.67-1.07 V, 2.8-10.2), woodwardite and allofan (0.59-0.85 V, 5.7-11.8), alunogen (0.8-1.07 V, 2.8-7.9), olivenite (1.03-1.07 V, 2.7-2.8), and montmorillonite (0.57-0.62 V, 9.5-10.8). The following minerals (sulfide content, in \%) disappear: montmorillonite at $10 \%$; goethite and magnesite at $60 \%$; and gypsum, woodwardite, and allophane at $80 \%$; and the following appear: fibroferrite at $10 \%$, alunogen at $60 \%$, and olivenite at $80 \%$. Montmorillonite crystallizes in the range from 30 to $45^{\circ} \mathrm{C}$.

In the range of negative temperatures (Figure 11), the associations are as follows (Eh-pH): goethite, magnesite and allophane (0.5-0.7 V, 10.0-14.2), gypsum (0.5-1.1 V, 2.9-13.0), starkeyite and olivenite (0.5-1.1 V, 2.9-14.2), fibroferrite (0.6-1.1 V, 2.9-13.7), woodwardite (0.6-0.7 V, 10.0-13.1), alunogen (0.9-1.1 V, 2.9-6.1), scorodite (0.6-0.9 V, 5.5-12.5), and montmorillonite (0.5-0.6 V, 12.7-14.2). Montmorillonite disappears in the systems at a $20 \%$ sulfide content, and goethite, woodwardite, magnesite, and allophane at $80 \%$; however, the following appear: fibroferrite at $10 \%$, scorodite at $20-80 \%$ in the temperature range from -25 to $-10{ }^{\circ} \mathrm{C}$, and alunogen at $80 \%$.

When sphalerite is excluded (Figure 12) from the composition of oxidizing sulfides in the positive temperature range, the paragenesis of minerals (Eh-pH) forms as follows: goethite and magnesite (0.57-0.75 V, 7.4-11.5), gypsum (0.57-1.09 V, 2.5-11.4), fibroferrite (0.67-1.09 V, 2.5-10.1), woodwardite and allophane $(0.57-0.85 \mathrm{~V}, 5.7-11.5)$, alunogen $(0.79-1.09 \mathrm{~V}, 2.5-7.9)$, anglesite and baildonite (1.04-1.09 V, 2.5-2.8), duftite (0.67-1.09 V, 2.5-10.1), and montmorillonite (0.57-0.62 V, 9.5-11.5). Depending on the sulfide content in the system, the following disappear: montmorillonite at $10 \%$, goethite and magnesite at $60 \%$, woodwardite and allophane at $80 \%$; and fibroferrite and duftite appear at $10 \%$, alunogen at $60 \%$, and anglesite with baildonite at $80 \%$.

In the range of low temperatures (Figure 13) in the simulated systems, the following are found (Eh-pH): goethite, magnesite, and allophane (0.5-0.7 V, 9.3-14.4); starkeyite (0.5-1.1 V, 2.5-14.4); woodwardite (0.5-0.7 V, 10.1-14.4); gypsum (0.5-1.1 V, 2.5-13.0); fibroferrite (0.7-1.1 B, 2.5-10.1), duftite (0.5-0.7 V, 9.3-13.2); baildonite (0.5-1.1 V, 2.5-14.4); olivenite (0.5-0.9 V, 6.1-13.8); scorodite (0.6 V, 11.2-12.4); chalcantite (0.9 V, 6.1-7.1); alunogen (0.9-1.1 V, 2.5-7.1); anglesite (1.1 V, 2.5); and montmorillonite (0.5-0.6 V, 12.7-14.4). High pH values were found in models with high content of host rocks under cryogenic conditions; such systems contain sulfates (woodwardite, gypsum, etc.) with insignificant masses (from 0.00001 to $0.8 \mathrm{~g}$ )

In the system, the following disappear with different sulfide contents: montmorillonite at $20 \%$, goethite; and woodwardite, magnesite, duftite, bayldonite, and allophane at $80 \%$; and the following appear: fibroferrite and olivenite at $10 \%$, calcite only at $40 \%$, as well as chalcantite, alunogen, and anglesite at $80 \%$. Crystallization of a number of minerals is noted in a certain temperature range: starkeyite, olivenite, bayldonite, and montmorillonite at -25 to $-5{ }^{\circ} \mathrm{C}$; chalcantite at -25 to $-10{ }^{\circ} \mathrm{C}$; anglesite only at $0{ }^{\circ} \mathrm{C}$.

\subsection{Tailings Oxidation With Cementation Zone Sulfides}

We also examined the processes of sulfide oxidation in contact with the host rock (at the ratios of 5:95, 10:90, 20:80, 40:60, and 80:20) at the tailings dump of the Vysokogorsk deposit with the participation of cementation zone sulfides in the temperature range from 0 to $45^{\circ} \mathrm{C}$. Calculations included 19 independent (Al, Ar, As, B, C, Ca, Cu, Fe, K, Mg, N, Na, Pb, S, Si, Zn, H, O, and ē) and 368 dependent components: 283 dissolved particles, 18 gases, and 67 solid phases.

The following minerals crystallize from solutions in the following Eh- $\mathrm{pH}$ conditions: goethite, woodwardite, magnesite, duftite, and allophane (0.58-0.75 V, 7.4-11.8); fibroferrite and gypsum (0.67-1.0 V, 3.5-10.1), alunogen, olivenite, and baildonite (1.04-1.09 V, 2.5-2.8); antlerite (1.04-1.05 V, 2.8); posnjakite (1.05-1.06 V, 2.7); wroewolfeite (1.06-1.09 V, 2.5-2.6); and montmorillonite (0.56-0.62 V, 9.5-11.2). As it was seen previously, the masses of sulfates in high alkaline $\mathrm{pH}$ cases are insignificant. Montmorillonite is absent in systems with a sulfide content of $20 \%$ or more, and goethite, woodwardite, magnesite, duftite, and allophane at $80 \%$. The following minerals appear at various sulfide 
contents: gypsum at $10 \%$, fibroferrite at $20 \%$, and alunogen, antlerite, posnyakite, rovolfit, olivionite, and baildonite at $80 \%$.

Thus, the hypergenic minerals paragenesis formed from mine waters in mine workings (adits and quarries) is represented by the following minerals: fibroferrite, chalcantite, posnyakite, wroewolfeite, antlerite, goslarite, anglesite, baildonite, duftite, and olivenite. During oxidation of tailings in the temperature range from -25 to $45^{\circ} \mathrm{C}$, the association is characterized by goethite, gypsum, woodwardite, alunogen, fibroferrite, magnesite, allophane, and montmorillonite.

In the range of positive temperatures, in the absence of pyrite in the composition of sulfides, alunogen does not precipitate, and crystallization of anglesite is possible only in the presence of the enrichment of sulfide containing $\mathrm{Pb}$ (galena), duftite, and baildonite: $\mathrm{Cu}, \mathrm{Pb}$, and As. The presence of tenorite in paragenesis is observed only in the Khrustalnoe deposit. Antlerite, posnjakite, and wroewolfeite are present in the association when the tailings of the enrichment include minerals of the cementation zone or no arsenopyrite is present. Olivenite is deposited in the absence of galena or pyrrhotite in the system, as well as in the presence of minerals from the secondary sulfide enrichment zone.

In the range of negative temperatures, the association additionally includes starkeyite ( -25 to $-5{ }^{\circ} \mathrm{C}$ ). The models do not contain sulfide; if all sulfides are present in the enrichment wastes, there is no As (arsenopyrite), and olivenite, baildonite, and duftite do not precipitate without $\mathrm{Cu}$ and As (chalco- and arsenopyrite), nor do baildonite and duftite without $\mathrm{Pb}$ (galena). Anglesite crystallizes only in models without arsenopyrite and sphalerite, as well as wroewolfeite and chalcantite in the presence of all sulfides or in the absence of arsenopyrite.

The factors determining hypergenic and technogenic minerals paragenesis formation during the sulfide ores oxidation in the mining industrial technogenic system are the presence of sulfide in the simulated system, the relationship between sulfides and the host rock, and temperature.

Comparison with previously reported findings [2] showed that all hypergenic minerals formed during modeling were found and diagnosed in the mining and industrial technogenic system in the Kavalerovsky district.

The formation of mine water occurs when all micropore solutions, the variants of which are described above, are merged. The study of hydrochemical samples of mine waters has shown that in the studied area, the $\mathrm{pH}$ values are in the range from 4.5 to 8.1 [17].

\section{Conclusions}

Modeling of the oxidation of ores and the tailings sulfide component in the temperature range from -25 to $45{ }^{\circ} \mathrm{C}$ showed that the solutions formed have Eh-pH parameters of 0.42-1.24 V and 0.1-14.7. High alkaline $\mathrm{pH}$ values were found in micropore solutions in the temperature range from -5 to $-25{ }^{\circ} \mathrm{C}$ during mine waters formation (chalcocite and bornite oxidation), and formation of slurry and drainage waters (with high content of host rock minerals, from $60 \%$ to $95 \%$ ). In such cases, the sulfates are precipitated, but their masses are insignificant and amounts to $0.01-2 \%$ of total precipitated minerals masses.

The following minerals are crystallized in models: $\mathrm{Fe}, \mathrm{Cu}, \mathrm{Pb}, \mathrm{Zn}, \mathrm{Al}, \mathrm{Ca}$, and $\mathrm{Mg}$ from different classes, including oxides, hydroxides, sulfates, carbonates, arsenates, and silicates. Both monomineral and polymineral formations (up to 12 minerals) can precipitate from saturated solutions, as it was seen in natural conditions [2]. The association of crystallized secondary minerals depends on the ores and tailings composition, which includes the presence of a cementing zone in the mineral system or the absence of one of the sulfides. The ratio of sulfide to host rock in the model is an important factor.

The process of mineral formation, the mass of precipitated minerals, and the content of elements in human-made waters depends on temperature. Most of the precipitated minerals are observed throughout the selected temperature range, and some crystallize only within a certain range in either the negative or positive temperature range. In cryogenic conditions, the process of mineral formation is no less active than in the range of positive temperatures. The mass of precipitated minerals varies 
from one hundred thousandths to hundreds of grams. The concentration of sulfide ores and their host rock elements in solution in the range of positive temperatures is in the tens of grams per liter, and in cryogenic conditions, the solutions are more concentrated and reach hundreds of grams per liter as part of the water precipitates in solid form (ice). All elements both before and after the fallout of hypergenic and human-made minerals from solutions are released into surface and ground water.

The annual mass of pollutants washed away in the warm period (April-October) by rainwater and melt water into water bodies from only one tailings dump of the Dubrovskoe deposit was calculated as (kg): As, 288; $\mathrm{Cu}, 66 ; \mathrm{Pb}, 332 ; \mathrm{Zn}, 194$, and S, $1341 \mathrm{~kg}$ [14]. The total annual output of sulfide ore elements is more than 2.2 tons. Their content in modeled human-made waters exceeds background concentrations by 11,333 to 174,000 times, surpassing the maximum allowable concentration in fisheries by $1.7-34,659$ times, and for cultural and domestic water by $1.02-17,387$ times. Uncontrolled flow of such waters into the river network of the district will seriously negatively affect their quality. As drinking water in the Kavalerovsky district is withdrawn from the Vysokogorky brook, the quality control should be constant.

The obtained results showed that it is necessary to carry out a complex recultivation of tailings dumps, which are technogenic deposits, in the near future, taking into account the characteristics of solutions, revealed by physical and chemical modeling. At first, useful components should be extracted from tailings, otherwise they can be lost [27]. Consequently, all data can be used to develop specific methods for tailings management in both the area under consideration and other mining areas where sulphide-containing tailings are present.

Author Contributions: Conceptualization: V.Z.-investigation, methodology, data curation, writing original draft; A.L.- visualization, software; K.F.- supervision, project administration, software, validation, writing original draft, writing, review and editing. All authors have read and agreed to the published version of the manuscript.

Funding: The reported study was funded by RFBR according to the research project No. 18-35-00114.

Acknowledgments: We thank the two anonymous reviewers whose comments helped improve and clarify this manuscript.

Conflicts of Interest: The authors declare no conflict of interest.

\section{References}

1. Kavalerovsky Municipal District. Available online: http://www.kavalerovsky.ru/ (accessed on 1 November 2019).

2. Zvereva, V.P. Environmental Consequences of Hypergene Processes on Tin Ore Deposits of the Far East; Dal'nauka: Vladivostok, Russia, 2008; p. 165. (In Russian)

3. Krupskaya, L.T.; Cherentsova, A.A.; Mayorova, L.P.; Golubev, D.A. Determination of the environmental hazard class of waste accumulated by the former mining enterprise of the Far Eastern Federal District in the past century. Russ. J. Gen. Chem. 2016, 2, 86-90. (In Russian)

4. Karpov, I.K.; Chudnenko, K.V.; Bychinskii, V.A.; Kulik, D.A.; Avchenko, O.V. Minimization of Gibbs free energy in geochemical systems by convex programming. Geochem. Int. 2001, 39, 1108-1119.

5. Karpov, I.K.; Kiselev, A.I.; Letnikov, F.A. Simulation of Natural Mineral Formation on a Computer; Nedra: Moscow, Russia, 1976; p. 255. (In Russian)

6. Yokokawa, H. Tables of thermodynamic properties of inorganic compounds. J. Natl. Chem. Lab. Ind. 1988, 83, 27-118.

7. SUPCRT Database 2007 Geopig, Arizona State University. Available online: http://geopig.asu.edu/sites/ default/files/slop07.dat (accessed on 18 April 2015).

8. Robie, R.A.; Hemingway, B.S. Thermodynamic Properties of Minerals and Related Substancies of $298.15 \mathrm{~K}$ and 1 Bar Pressure and at Higher Temperatures; US Geological Survey: Washington, DC, USA, 1995; p. 461.

9. Chudnenko, K.V. Thermodynamic Modeling in Geochemistry: Theory, Algorithms. Software, and Applications; GEO Publishing House: Novosibirsk, Russia, 2010; p. 287. (In Russian)

10. Yeriomin, O.V. Calculation of standard thermodynamic potentials for Na-zeolites with the use of linear programming problems. Int. J. Geosci. 2011, 2, 227-230. [CrossRef] 
11. Charykova, M.V.; Krivovichev, V.G.; Depmeir, W. Thermodynamics of arsenates, selenites, and sulfates in the oxidation zone of sulfide ores: I. Thermodynamic constants at ambient conditions. Geol. Ore Depos. 2010, 52, 689-700. [CrossRef]

12. Horne, R.A. Marine Chemistry; Wiley-Interscience, A Division of John Wiley \& Sons: New York, NY, USA, $1969 ;$ p. 568.

13. Gonevchuk, V.G. Tin-Bearing Systems of the Far East: Magmatism and Ore Genesis; Dal'nauka: Vladivostok, Russia, 2002; p. 295. (In Russian)

14. Pyatakov, A.D. Assessment of the Kavalerovsky District Tin-Sulfide Deposits Mining Technogenic System Impact on Hydrosphere Using Physico-Chemical Modeling Method. Ph.D. Thesis, Far Eastern Federal University, Vladivostok, Russia, 14 June 2017. (In Russian).

15. Vasilenko, G.P. The Final Report on the Results of Research under the Program of the USSR State Committee for Science and Technology «Rational Use of Mineral Raw Materials»; DVGI DVO AN SSSR: Vladivostok, Russia, 1989; p. 54. (In Russian)

16. Zvereva, V.P.; Pyatakov, A.D.; Kostina, A.M.; Lysenko, A.I.; Frolov, K.R. Physico-chemical parameters of the formation of supergene and technogenic minerals in the mining technogenic systems of Russian Far East. Russ. J. Gen. Chem. 2015, 85, 2956-2960. [CrossRef]

17. Zvereva, V.P. Impact of Technogenic Wastewaters of Kavalerovskii and Dalnegorskii Mining Districts on the Hydrosphere of Primorsky Krai. Ekol. Khimiya 2019, 28, 199-210. (In Russian)

18. Zvereva, V.P.; Pyatakov, A.D.; Kostina, A.M.; Frolov, K.R.; Lysenko, A.I. Physicochemical modeling of the impact of tailings dumps in the Kavalerovskii tin-ore district of the Russian far east on the hydrosphere. Russ. J. Gen. Chem. 2013, 83, 2663-2667. [CrossRef]

19. Zvereva, V.; Pyatakov, A.; Kostina, A. Modeling of sulfide oxidation in tailings dumps of the Kavalerovsky district and their impact on the hydrosphere (Primorsky Krai, Russia). Russ. J. Gen. Chem. 2014, 83, 2750-2753. [CrossRef]

20. Zvereva, V.; Pyatakov, A.; Kostina, A. Physicochemical modeling of slime and drainage waters of Vysokogorskoye tailing dump and their impact on the hydrosphere (Far East of Russia). WIT Trans. Built Environ. 2014, 145, 475-481.

21. Zvereva, V.P.; Pyatakov, A.D.; Lysenko, A.I.; Kostina, A.M. Estimation of effect of polymetallic ore tailing dumps on hydrosphere using physicochemical modeling method (Primorsky region). WIT Trans. Built Environ. 2014, 88, 493-498.

22. Kostina, A.; Zvereva, V.; Pyatakov, A. Influence of sulfur content in tailings on processes of hypergene and technogene mineral formation on the example of Kavalerovo tin-ore district. Adv. Mater. Res. 2014, 1051, 605-609. [CrossRef]

23. Zvereva, V.P.; Frolov, K.R.; Lysenko, A.I.; Pyatakov, A.D. Ecological-Chemical Estimation of the Impact of Hypergene Processes Occuring in Sulfide-Bearing Wastes of the Mining-Industrial Technogene Systems of the Far East on the Hydrosphere with the Method of the Physicochemical Modeling; Far Eastern Federal University: Vladivostok, Russia, 2016; p. 287. (In Russian)

24. Zvereva, V.P.; Pyatakov, A.D. Physicochemical Modeling of Sulfide Oxidation Processes in Tailing Dumps of the Kavalerovsky District and Their Impact on the Hydrosphere (Primorsky Krai). Russ. J. Gen. Chem. 2017, 87, 3137-3143. [CrossRef]

25. Zvereva, V.P.; Pyatakov, A.D. Behavior of Sulfide Ore Elements in the Oxidation of Concentration Tailings under Cryogenic Conditions (Dalnegorsk District, Far East). Russ. J. Gen. Chem. 2018, 87, 2976-2981. [CrossRef]

26. Frolov, K.R.; Lysenko, A.I.; Pyatakov, A.D. A Study of the Qualitative Chemical Composition of Technogenic Waters in the Tailing Dumps of the Russian Southern Far East in a Wide Temperature Range Using the Physicochemical Modeling Method. IOP Conf. Ser. Earth Environ. Sci. 2019, 272, 022124. [CrossRef]

27. Bortnikova, S.B. Geochemistry of Heavy Metals in Technogenic Systems: Problems of Formation, Development and Interaction with Components of the Ecosphere. Ph.D. Thesis, IPGG SB RAS, Novosibirsk, Russia, 23 December 2001. (In Russian).

(C) 2020 by the authors. Licensee MDPI, Basel, Switzerland. This article is an open access article distributed under the terms and conditions of the Creative Commons Attribution (CC BY) license (http://creativecommons.org/licenses/by/4.0/). 